\title{
Development Comic Based Problem Solving in Geometry
}

\section{Pardimin $^{a}$ and Sri Adi Widodo ${ }^{a}$}

\author{
aUniversitas Sarjanawiyata Tamansiswa, INDONESIA
}

\begin{abstract}
Learning devices are tools or equipment to carry out the process that will enable educators and learners perform the learning activities. Learning media is one of the learning tools that support the success of the learning process. This article discusses the development of instructional media for students of classes VII comics on rectangular material. This comic instructional media $4 \mathrm{D}$ method that is designed to define, design, development, and dissemination. In the first phase done to establish and define the terms of development, the second phase of the comic instructional media designed to obtain a prototype or product design and development phase is done with the media to determine the feasibility prototype, and prototype revision in order to obtain a hypothetical media. The results of the assessment sheet obtained that the feasibility media validator obtained an average score of 3.93 with very good. The process of developing a comic on the subject of geometry only through 3 phases: define, by analyzing the curriculum, and to formulate basic competencies and indicators of achievement of learning outcomes, the design phase is done by creating a comic prototype-based troubleshooting with a black and white design, develop.
\end{abstract}

KEYWORDS

Problem Solving; Comic; Geometry
ARTICLE HISTORY

Received 24 November 2016

Revised 29 December 2016

Accepted 19 January 2017

\section{Introduction}

The low student achievement can be due to the ability of learners in solving mathematical problems is inadequate, it can be shown that the learners to solve mathematical problems always just do the steps replied only, while steps to understand, plan and looking back the answer sometimes is not done (Widodo, 2012; 2013; 2014; 2017; Widodo and Sujadi, 2015; Pardimin and Widodo, 2016). In addition, most of the teachers are difficult to teach students about ways to solve a problem, so they hold that the final result was the only goal in problem-solving (Maula, Rohmad and Tirtosoekotjo, 2013). Whereas in mathematical problem solving, the end result is not only a destination but a

CORRESPONDENCE Pardimin $\square$ sriadi@ustjogja.ac.id

( 2017 Pardimin \& Sri Adi Widodo. Open Access terms of the Creative Commons Attribution 4.0 International License (http://creativecommons.org/licenses/by/4.0/) apply. The license permits unrestricted use, distribution, and reproduction in any medium, on the condition that users give exact credit to the original author(s) and the source, provide a link to the Creative Commons license, and indicate if they made any changes. 
process to solve the problem is important in solving problems. Due to the process of solving the problem, educators can determine whether students have understood the mathematical concept or not. In addition to problem-solving, math becomes lost meaning, because a concept or principle be meaningful if it can be applied in problem-solving (Sri Adi Widodo, 2015). It is the background that becomes important problem-solving skills in mathematics.

In addition to the students, teachers also have an important role in learning, especially to improve the quality of learning. To attract students', teachers are expected to use a varied learning model. The math teacher had a tendency to only focus on textbooks and are accustomed to using the lesson by presenting the learning materials, giving examples of problems and ask the students do practice questions contained in the textbooks they use in teaching and then discuss it with students (Nurgoho 2011; Efendi, 2012).

In the context of the Curriculum 2013, which is used in Indonesia, teachers are required to be able to meet a number of principles specific learning, such as teacher should consider the needs and individual differences, develop learning strategies that allow students active, creative, and fun, as well as assessing the process and student learning outcomes accurately and comprehensively.

Learning devices are tools or equipment to carry out the process that will enable educators and learners perform the learning activities (Prasetyo, et al, 2011). The preparation of learning tools that are part and parcel of the learning plan is designed in the form of a syllabus, lesson plans, preparation of learning media and learning resources, assessment tools, and learning scenarios (Permendikbud No. 65 of 2013). One of the learning tools that are used during the learning process includes instructional media.

Learning media become a determining factor for learners to participate in the process learning and create interest in the material to be taught. This is because the learning media can be used to deliver a message from the sender (teacher) to recipients (students) to stimulate the mind, feelings, concerns, or the willingness of students that will encourage the process of learning. To produce active learning, easy to understand, and fun for students requires a learning model that enables students to actively participate in the learning process, a learning process that makes students active participation during the learning process and student interest can be created by learning to use the device (Supriyono, Setiawan and Trapsilasiwi, 2014).

Educators need to think about ways of presenting and mathematics learning atmosphere that allows students easily understand and get excited to learn math. One effort to do is familiarize mathematics to real life. In other words, the teachers need to associate learning math concepts with experience in everyday life. The results showed that the instructional media used in mathematics learning is very effective (Bulut, Akçakın, Rich, \& Akçakın, 2016; Wibowo, 2013; Ismail, Sugiman \& Hendikawati, 2013; Yuniati, Bambang EP, and Gesang KN 2011; and Ali, 2009).

The problem is the medium used was based on information technology are like GeoGebra, flash, or PowerPoint. The weakness of information technology-based media such as a learning tool in the classroom to support the availability of devices such as computers, LCD, and projector. Based on this, the 
print instructional media would still be required for students who are in school with the support of information technology is still minimal. One example of the print media that can be used in mathematics is comic. Comics are learning media teaching materials pictorial form. Additionally selected comics as a medium of learning for the comic's mathematics learning during formal expected to close in the lives of learners so that learners become interested in reading and studying the mathematical concepts that are abstract.

\section{Methodological Framework}

This research is research development. Research development is research used to develop or produce products or enhance existing products (Sugiyono, 2009; Sukmadinata, 2005). The development of the investigational product is a comic teaching material on the subject of geometry for junior high school students of class VII.

Model development of teaching materials geometry refers to the 4-D models developed by Thiagarajan, and Semmel Semmel (1974), which define, design, development, and dissemination. The advantages of the model 4-D include: more appropriate to use as a basis for developing learning device is not to develop a learning system, the description seems complete and systematic in its development involves the assessment of experts, so that prior to being fieldtested learning device has been revised based assessment, advice and input of experts (Yusnita 2011; Wahyudi, Hariyadi, \& Hariani, 2014).

In the define phase, carried out to establish and define the terms of development. Generally, at this defining stage of development needs analysis conducted activities, the terms of the development of products according to user needs as well as research and development models suitable for developing products. The analysis can be done through the study of literature or the preliminary study. In determining and establishing the terms of the learning device starts with (a) the analysis of the curriculum, (b) analysis of the characteristics of learners, (c) analysis of the material, and (d) formulate objectives.

At the design stage, has prepared a draft prototype learning device. At this stage to make teaching materials in accordance with the contents of the analysis results framework curriculum and materials. Prior to the design of products (materials hypothetic) proceed to the next stage, then the hypothetical teaching materials need to be validated. Validation of product design by a team of expert judgment (team of experts) as a professor or teacher of mathematic through Focus Group Design (FGD). Based on the results of the focus group, there is the possibility of product design needs to be improved in accordance with feedback or suggestions at the time of the FGD.

In the early development stage, has acquired the comic instructional materials are hypothetical and math learning problem-solving test instruments and good fit. Comic instructional materials are hypothetical mathematical learning is used as one of the requirements to conduct limited testing to be conducted in the second year. While the problem-solving test instruments that have been tested are also used to obtain data on math problem-solving skills and learning achievement will be used to measure the effectiveness of mathematics teaching materials comics. Where the measurement of the effectiveness of mathematics teaching materials comics will be made in the second year and 
third year as an integral continuation of this study. This study only reached the stage of development, while the deployment phase (disseminate) can not be done. This is because the distribution and adoption of instructional materials must fit their comic do by the school curriculum.

These criteria include the quality of mathematics learning comic validity criteria, practicality and effectiveness (Sholihah, Susanto, \& Sugiarti, 2015). Criterion validity is done by presenting experts in the field of mathematics, namely comic professor of mathematics education as an expert in the field of mathematics materials, professors of art and art as an expert practitioner in the field of art or comics. Practicality criteria based on the activity of teachers in managing learning. While the effectiveness criteria would be effective between the usual lesson with the teacher teaching mathematics using the comic to the ability to solve mathematical problems.

\section{Result}

In this study produced comics on the subject of mathematics learning in terms of four for junior high school students of class VII. The results of material development aim to approach rectangular material to students so that the students, so that students become easier to learn the material in terms of four when compared to using books ni materials for use by teachers. Besides cognitive development Piaget, grouping students of class VII are informal cognitive development (abstract) for their age range over 12 years (Widodo, 2010). But they still have the mindset of concrete and semi-formal, so it takes a medium of learning and teaching materials that are able to facilitate the students' cognitive developmental differences.

To view, the validity of mathematics learning comics does with the validity of the content. The validity of the contents indicates that the contents of teaching materials were not developed at random, but should be justified scientifically and correctly in terms of science. The indicators or aspects of teaching materials comics validation refer to (1) aspect of comic structure, (2) a material aspect, (3) aspects of the organization, presentation and writing, and (4) aspects of language and legibility. Analysis of data obtained from a descriptive form validator assessing the feasibility of teaching materials with a value between 1 to 5 in each indicator, suggestions, and comments. Data from the feasibility assessment obtained teaching materials categorized as follows.

Table 1. Average Classification Comic Mathematics Learning Validation

\begin{tabular}{|c|l|}
\hline Interval & \multicolumn{1}{|c|}{ classification } \\
\hline $5,00 \leq \bar{x} \leq 3,75$ & Very good \\
\hline $2,92<\bar{x} \leq 3,75$ & Good \\
\hline $1,67<\bar{x} \leq 2,92$ & fair \\
\hline $1,25<\bar{x} \leq 1,67$ & less \\
\hline $1,00 \leq \bar{x} \leq 1,67$ & Very less \\
\hline
\end{tabular}

While comics mathematics rated valid if the average score earned at least 2.92 for each aspect of comics assessment of learning. 
Based on the validation of the validator and once calculated based on criteria validation by investigators then obtained the following results.

Table 2. Results Validation Mathematics Learning Comics

\begin{tabular}{|c|l|c|l|}
\hline No & \multicolumn{1}{|c|}{ indicator } & mean & conclusion \\
\hline 1 & Comic Structur & 4,02 & Very good \\
\hline 2 & Content & 4,02 & Very good \\
\hline 3 & Organization, Presentation and Writing & 3,93 & Very good \\
\hline 4 & Language and Readability & 4,06 & Very good \\
\hline
\end{tabular}

From the results of the validation test comics mathematics (Table 2), it can be concluded that the average for appraisal aspect not obtained a minimum of 3.93. This means that comics can be expressed in mathematical learning valid in the excellent category.

In practicality criteria based on the activities of teachers in managing learning, researchers act as observers to observe the activities of teachers in managing learning. Comic mathematics rated practical (applicable) if the level of achievement of the teacher's ability to manage the learning of at least $75 \%$.

In general, learning using teaching materials that have been developed judged good, it's just not good time management. From the analysis of the data, obtained by the percentage of teachers in managing learning activities in the first meeting reached $76.5 \%$, in the second meeting reached $80.5 \%$, and at the third meeting reached $85.5 \%$. The average percentage of teachers in managing learning activity reached $80.83 \%$. It can be concluded that the comic study of mathematics can be expressed practically used for the learning of mathematics in the rectangular material.

On the criteria of effectiveness, comics mathematics declared effective if less significance coefficient of 0.05 using the Mann-Whitney U test. The results of the Mann-Whitney U calculation with SPSS shows that $h=121,000$ with a coefficient of 0.000 significance, but it's average ranking in learning by using a comic study of mathematics at 40.47 and the average rating on learning that does not use the comic study of mathematics at 19.17. Based on this it can be concluded that the use of comics mathematics effectively used in mathematics.

\section{Discussion}

Phase defining the first stage in the development of teaching materials comics. This stage is to establish and define the terms of development. In general, the definition phase is implemented through the development of needs analysis, requirements development of products that comply with the needs of users as well as research and development models suitable for developing products. In determining and establishing the terms of the learning device begins with curriculum analysis, material analysis, and formulate objectives.

The curriculum studied is the Kurikulum Tingkat Satuan Pendidikan (KTSP) this is because the Ministry of Education and Culture (Education) has issued a circular No. 179342 / MPK / KR / 2014 dated December 5, 2014, on the Implementation of Curriculum 2014. Where one of the rules is to stop the implementation of the curriculum 2013 in the new schools implementing one 
semester, ie since the school year 2014/2015. These schools are expected to reuse the curriculum in 2006 back from the second semester of the Academic Year 2014/2015. The circular is reinforced by Minister of Education and Culture, Republic of Indonesia Number 160 of 2014 On Implementation of Curriculum 2006 and Curriculum 2013. Where permendikbud stated that basic education units and implementing secondary education curriculum in 2013 since the first half of the school year 2014 / 2015 re-implement the curriculum in 2006 began the second half of the school year 2014/2015 until there is a provision of the Ministry to implement Curriculum 2013 and Unit of primary education and secondary education curriculum can carry a maximum of 2006 until the academic year 2019/2020.

In the seventh-grade geometry material analysis, researchers chose a rectangular material that will be developed as a teaching material in the form of comics. The rectangular material consists of (1) a square, (2) rectangular, (3) a parallelogram, (4) rhombus, (5) the trapezium, and (6) the kite. The next step we propose or use the existing basic competencies and indicators of achievement of learning outcomes that are based on core competencies.

At the design, stage researchers designed comic teaching materials in order to obtain a prototype or product design. At this stage made teaching materials in accordance with the contents of the analysis results framework curriculum, material analysis, and formulate objectives on the material of the rectangle.

The design of instructional materials is done by selecting the shape like a comic that sold namely black and white comics. This is because of the black and white comics more familiar than the colored comics. As in the comic Doraemon or other online comics in the form of black and white. Teaching materials for rectangular material consist of two parts interconnected comic are Beautiful Bangun Datar and Travels of Three Companions. Build Beautiful Flat comic tells the story of a rectangular material and a parallelogram, while the comic journey of three friends told him about the material square, rhombus, kite, and trapezoid.

The activities include the development phase (1) conduct a feasibility assessment or prototype or comic product design teaching materials, and (2) revised prototype or product design teaching materials comics based on input from the validator to obtain teaching materials comics are hypothetical.

Expert assessment process carried out during the Focus Group Design (FGD), which was attended by lecturers of mathematics education (subject matter experts mathematics), professor of art education or (expert comic strips), and junior high school mathematics teachers (education practitioners). Comic instructional materials to be eligible if obtained averages at least 2.92 or at least be in the category enough. Based on Table 1 to Table 4 obtained average at least 3.93 with very good categories for every aspect of the assessment of teaching materials comics. Based on these results it can be concluded that the comic instructional materials that have been developed have excellent comic structure, excellent material aspects, aspects of the organization, presentation and writing excellent category and aspects of language and very good legibility. Based on these results comics teaching materials can be used in small-scale trials. 
Although the terms of eligibility in the excellent category, the validator to provide input and comments to revise teaching materials comics. The input of the validator include (1) on a comic journey of three friends, the definition of a kite needs to be considered because it raises a double meaning, (2) there is a calculation error and sample on the sample questions either in comics, (3) comic journey of three friends and flat beauty to be made in color.

Menyingkapi input from the validator then to the definition of kites on a comic journey of three friends replaced with a "wake-up rectangle has exactly two pairs of sides equal in length that meet at a point" where previously defined with a "wake-up flat rectangle formed from triangle isosceles the soles of the same length and coincide ". errors that occur in black and white comics can be improved, while comic prototype made of black and white in the redesign into colors.

\section{Conclusion}

The process of developing a comic on the subject of geometry only through 3 phases: define, by analyzing the curriculum, and to formulate basic competencies and indicators of achievement of learning outcomes, the design phase is done by creating a comic prototype-based troubleshooting with a black and white design, develop. Based on the comic quality criteria covering mathematics validity, practicality and effectiveness can be concluded that the comic mathematics learning is feasible and can be used to carry out the teaching and learning activities.

\section{Disclosure statement}

No potential conflict of interest was reported by the authors.

\section{Notes on contributors}

Pardimin - Universitas Sarjanawiyata Tamansiswa, Indonesia

Sri Adi Widodo - Universitas Sarjanawiyata Tamansiswa, Indonesia

\section{References}

Ali, M. (2009). Pengembangan Media Pembelajaran Interaktif Mata Kuliah Meda Elektromagnetik. Jurnal Edukasi @Elektro, 5(1), 11 - 18.

Bulut, M., Akçakın, H.U., Kaya, G \& Akçakın, V. (2016). The Effects of GeoGebra On Third Grade Primary Students' Academic Achievement in Fractions. International Electronic Journal of Mathematics Education (IEJME), 11(2), $347-355$.

Effendi, L.A. (2012). Pembelajaran Matematika Dengan Metode Penemuan Terbimbing Untuk Meningkatkan Kemampuan Representasi Dan Pemecahan Masalah Matematis Siswa SMP. Jurnal Penelitian Pendidikan, 13(2), 1 - 10.

Ismail, A.K., Sugiman \& Hendikawati, P. (2013). Efektivitas Model Pembelajaran Teams Group Tournament Dengan Menggunakan Media "3 in 1" Dalam Pembelajaran Matematika. Unnes Journal of Mathematics Education, 2(2), 25 - 32. 
Maula, N., Rohmad \& Soedjoko, E. (2013). Keefektifan Pembelajaran Model TAPPS Berbantuan Worksheet Terhadap Kemampuan Memecahkan Masalah Materi Lingkaran. Unnes Journal of Mathematics Education (UJME), 2(1), 19 - 27.

Nugroho, A.A. (2011). Pengembangan Perangkat Pembelajaran Matematika Berbasis SMART Dengan Strategi TAI Pada Materi segitiga Kelas VII. Jurnal Aksioma, 2(2).

Pardimin \& Widodo, S.A. (2016). Increasing Skills of Student in Junior High School to Problem Solving in Geometry with Guided. Journal of Education and Learning, 10(4), 390-395.

Permendikbud No. 65 Tahun 2013 tentang Standar Proses Pendidikan Dasar dan Menengah

Prasetyo, Z. K, et al. (2011). Pengembangan Perangkat Pembelajaran Sains Terpadu Untuk Meningkatkan Kognitif, Keterampilan Proses, Kreativitas serta Menerapkan Konsep Ilmiah Peserta Didik SMP. Postgraduate program UNY.

Sholihah, W., Susanto, \& Sugiarti, T. (2014). Pengembangan Bahan Ajar (Buku Siswa) Matematika Untuk Siswa Tunarungu Berdasarkan Standar Isi Dan Karakteristik Siswa Tunarungu Pada Sub Pokok Bahasan Menentukan Hubungan Dua Garis, Besar Sudut, Dan Jenis Sudut Kelas Vii Smplb/B Taman Pendidikan Dan Asuhan (TPA) Jember Tahun Ajaran 2012/2013. Jurnal Pancaran, 4(1), 219 - 228.

Sugiyono. (2009). Metode Penelitian Pendidikan: Pendakatan Kualitatif, Kuantitatif, dan R\&D. Bandung: Alfabeta.

Sukmadinata, N. S. (2005). Metode Penelitian Pendidikan. Jakarta: PPS UI dan Remaja Rosdakarya.

Supriyono, Setiawan, T. B., \& Trapsilasiwi, D. (2014). Pengembangan Perangkat Pembelajaran Matematika Model Student Facilitator And Explaining Setting Contextual Teaching And Learning (CTL) Pada Sub Pokok Bahasan Prisma dan Limas Kelas VIII Semester Genap. Jurnal Pancaran, 3(2), 53-62.

Thiangarajan S., Semmel D., \& Semmel M. I. (1974). Instructional Development For Training Teachers Of Exceptional Children: A Sourcebook. Minneapolis: Central for Innovation on Teaching the Handicapped.

Wahyudi, B.S., Hariyadi, S., \& Hariani, A.S,. (2014). Pengembangan Bahan Ajar Berbasis Model Problem Based Learning Pada Pokok Bahasan Pencemaran Lingkungan Untuk Meningkatkan Hasil Belajar Siswa Kelas X SMA Negeri Grujugan Bondowoso. Jurnal Pancaran, 3(3), $83-92$.

Wibowo, E.J. (2013). Media Pembelajaran Interaktif Matematika Untuk Siswa Sekolah Dasar Kelas IV. Seruni: Seminar Riset Unggulan Nasional Informatika dan Komputer. 75 - 78.

Widodo, S. A. (2010). Permasalahan Pengajaran Matematika Di Sekolah Menengah Ditinjau Dari Teori Perkembangan. Majalah Ilmiah Wacana Akademika, 3(8).

Widodo, S. A. (2017). Development of Teaching Materials Algebraic Equation To Improve Problem Solving. Infinity, 6 (1), 61-70

Widodo, S.A \& Sujadi, A.A. (2015). Analisis Kesalahan Mahasiswa Dalam Memecahkan Masalah Trigonometri. Jurnal Sosiohumaniora, 1(1), 51-63.

Widodo, S.A. (2012). Proses Berpikir Mahasiswa Dalam Menyelesaikan Masalah Matematika Berdasarkan Tipe Kepribadian Idealist. Laporan Penelitian. Yogyakarta: UST

Widodo, S.A. (2013). Analisis Kesalahan Dalam Pemecahan Masalah Divergensi Tipe Membuktikan Pada Mahasiswa Matematika. Jurnal Pendidikan Dan Pengajaran, 46(2), 106 - 113.

Widodo, S.A. (2014). Kesalahan dalam Pemecahan Masalah Divergensi pada Mahasiswa Matematika. Jurnal Admathedu, 4(1).

Widodo, S.A. (2015). Keefektivan Team Accelerated Instruction Terhadap Kemampuan Pemecahan Masalah dan Prestasi Belajar Matematika Siswa Kelas VIII. Jurnal Kreano: Jurnal Matematika Kreatif Dan Inovatif, 6(2), 127 - 134

Yuniati, N., Bambang E.P, Gesang K.N. (2011). Pembuatan Media Pembelajaran Interaktif Ilmu Pengetahuan Alam Pada Sekolah Dasar Negeri Kroyo 1 Sragen. Journal Speed: Sentra Penelitian Engineering dan Edukasi, 3(4), 25-29. 
Yusnita, E. 2011. Pembelajaran Kontekstual berlatar pondok pesantren pada materi garis dan sudut di kelas VII MTS. Prosiding Seminar Nasional Matematika Dan Pendidikan Matematika UNY. PM -11 - PM 18. 